\title{
УДК 553.7 \\ ДАГИНСКОЕ МЕСТОРОЖДЕНИЕ ТЕРМАЛЬНЫХ МИНЕРАЛЬНЫХ ВОД. УСЛОВИЯ ФОРМИРОВАНИЯ, СОВРЕМЕННОЕ СОСТОЯНИЕ, ПЕРСПЕКТИВЫ ИСПОЛЬЗОВАНИЯ (САХАЛИНСКАЯ ОБЛАСТЬ)
}

\author{
Сахаров Валерий Александрович1, \\ sakhsakh@yandex.ru
}

Ильин Владимир Вениаминович1, vladimirilyin7@gmail.com

Морозова Ольга Анатольевна1, sgi84@mail.ru

Выпряжкин Евгений Николаевич ${ }^{1}$, e_vipryashken@mail.ru

\section{и Кен Хиㅜ,} Sakhgu@list.ru

Гоголева Ирина Владимировна 1 , risha.89@mail.ru

1 Сахалинский государственный университет,
Россия, 693008, г. Южно-Сахалинск, ул. Пограничная, 68.

\begin{abstract}
Актуальность исследования обусловлена потребностью расширения использования ресурсной базы минеральных вод бальнеологического назначения, приближенной к потребителю, оценки лечебных свойств минеральных вод на основе изучения опыта их эксплуатации, соответствия требованиям актуальных руководящих документов. Развитие этого направления позволит нарастить объем и увеличить спектр лечебных и профилактических услуг с использованием местных природных минеральных вод с минимизацией капитальных затрат на геологоразведочные работы.

Цель: изучить строение, современное состояние и опыт эксплуатации Дагинского месторождения термальных минеральных вод (Сахалинская область), оценить перспективы расширения бальнеологических и туристических услуг, разработать рекомендации по промышленному освоению месторождения.
\end{abstract}

объекты: минеральные термальные воды, их свойства и условия распространения на земной поверхности и в гидрогеологическом разрезе.

Методы: изучение фондовых и архивных документов о геологическом строении и гидрогеологических условиях района исследований, натурное обследование современного состояния месторождения, гидрохимическое опробование отдельных источников, опрос потребителей минеральных вод.

Результаты. Дана геолого-гидрогеологическая характеристика месторождения термальных минеральных вод. Определены бальнеологические свойства вод на различных участках месторождения в соответствии с актуальными руководящими документами. Представлено современное состояние использования термальных минеральных вод. Разработаны рекомендации по эксплуатации месторождения.

Выводы. Многолетней эксплуатацией Дагинского месторождения доказана высокая бальнеологическая эффрективность термальных минеральных вод. Месторождение сформировано путем смешения глубинных горячих минерализованных вод с приповерхностными холодными и пресными подземными водами. Разрывной тектоникой месторождение разбито на три участка. Подземные воды напорные. На участке месторождения наблюдается более 60 восходящих источников термоминеральных вод. Воды горячие слабо- $и$ среднеминерализованные, хлоридные натриевые, бромные, йодные (Северный участок) и гидрокарбонатно-хлоридные натриевые (Центральный и Южный участки). Балансовые эксплуатационные запасы утверждены по категориям $B+C_{1}+C_{2}$ в количестве 2500 $M^{3} /$ сутm. Воды в источниках обладают широким спектром медицинских показателей по применению. В настоящее время месторождение эксплуатируется «диким образом». Воды используются в основном для принятия ванн на источниках. Посещаемость источников в летнее время достигает 300 чел./еень. В зимний период посещение источников затруднено. Имеются хорошие перспективы для многократного увеличения количества посещений без капитальных затрат на геологическую разведку месторождения. Термальные минеральные воды месторождения обладают очень высокой биологической активностью. Бесконтрольное применение вод вместо лечебного, может привести к негативному эффректу. Известны случаи летальных исходов после чрезмерно длительного принятия ванн в источниках. Необходимо провести всестороннее исследование бальнеологических свойств вод различных источников и разработать рекомендации по методике их применения. Также необходимо организовать мониторинг источников с целью определения времени восстановления воды после посещения и разработать режим приема ванн.

\section{Ключевые слова:}

Термальные минеральные воды, термоминеральный источник, бальнеологические свойства воды, геотермический градиент, разрывная тектоника. 


\section{Введение}

В административном отношении Дагинское месторождение термальных минеральных вод находится в Ногликском районе Сахалинской области. Расположено в северной части о. Сахалин, на его восточном побережье, в 1 км от устья в правобережной части р. Нельбуты, в 30 км к северу от районного центра пос. Ноглики. Площадь выхода на поверхность земли термальных минеральных источников составляет около 0,5 км² $^{2}$ (рис. 1).

\section{Краткие сведения о месторождении}

Целебная сила Дагинских термоминеральных источников известна давно. Они пользуются большой популярностью как у местных жителей, так и за пределами области.

В 1951 г. было впервые произведено их специальное обследование В.М. Левченко. Им отобраны первые две пробы воды из источников на химические анализы. В августе 1963 г. более детально Дагинские источники обследованы комплексной конторой «Геоминвод» Центрального НИИ курортологии и физиотерапии (ЦНИИКиФ) под руководством В.В. Иванова при изучении курортных ресурсов о. Сахалина. В последующие годы район Дагинских источников исследовался в связи с изучением гидрогеологии нефтеносных отложений Северного Сахалина. Летом 1969 г. конторой «Геоминвод» ЦНИИКиФ проведены детальные комплексные исследования термальных вод Дагинских источников и грязевых отложений района. Силами этой же организации в 1972 г. при комплексном обследовании минеральных вод и лечебных грязей о. Сахалин на Дагинских источниках были отобраны пробы воды на полные физикохимические анализы из основных источников, измерена температура более чем в 60 источниках.

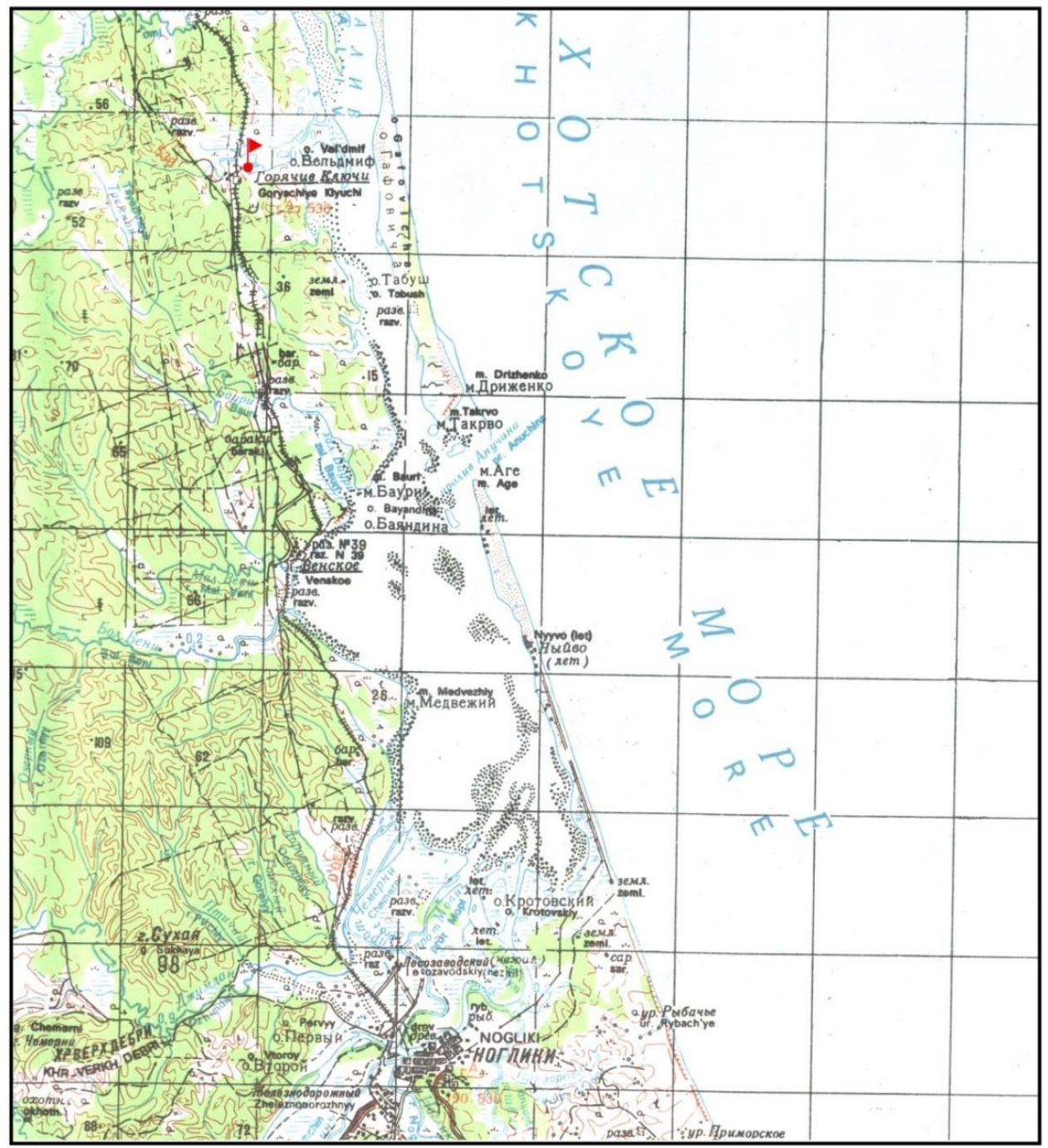

км $2 \quad 1 \quad 0 \quad 1 \quad 2$ км

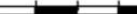

\section{- участок месторождения "Даги”}

Pис. 1. Обзорная схема расположения месторождения

Fig. 1. Overview layout of the field 
В 1988 г. Сахалинской гидрогеологической экспедицией было проведено обследование каптированных источников, оценены ресурсы источника «Центральный» (А.Ф. Прядко, В.Е. Прядко). Результаты этих исследований опубликованы не были, хранятся в архиве Сахалинской гидрогеологической экспедиции (г. Южно-Сахалинск). Одновременно сотрудником Южно-Сахалинского педагогического института В.А. Ведмицким, в рамках той же работы, были детально рассмотрены бальнеологические свойства термоминеральных вод.

Эксплуатация месторождения осуществляется на очень низком уровне. В пос. Горячие Ключи в конце $\mathrm{XX}$ в. действовала водолечебница на 35 койко-мест. В летнее время до 200 человек в день принимали ванны «диким» образом.

Некоторые источники каптированы, как правило, примитивными сооружениями и находятся в антисанитарном состоянии (рис. 5-10).

Общие естественные ресурсы месторождения очень осторожно оценены А.Ф. Прядко (1991) в количестве 15-20 л/с по результатам кратковременных пробных откачек и замеров дебита каптированных источников.

В 1990-1991 гг. на месторождении силами Сахалинской гидрогеологической экспедиции проведена разведка термальных минеральных подземных вод. Было пробурено и исследовано 5 поисковых и 1 наблюдательная скважины (рис. 3), выполнены наземные геофизические исследования и химические анализы воды. Глубина изучения - $180 \mathrm{M}$.

В результате территориальной комиссией по запасам полезных ископаемых при «Сахалингеолкоме» (ТКЗ) утверждены балансовые эксплуатационные запасы минеральных хлоридных натриевых, азотно-метановых, слабощелочных вод в количестве $2500 \mathrm{~m}^{3} /$ сут. (табл. 1) (Протокол № 63 от 07 июня 1993 г.).

В современной литературе Дагинские источники упоминаются достаточно часто, однако исследования носят поверхностный характер [1-10].

\section{Геологическое строение района исследований}

\section{Стратиграсрия}

В геологическом строении района работ принимают участие миоценовые отложения дагинской $\left(\mathrm{N}_{1} \mathrm{dg}\right)$ и окабыкайской $\left(\mathrm{N}_{1} \mathrm{ok}\right)$ свит и плиоценовые нутовской свиты
$\left(\mathrm{N}_{2} \mathrm{nt}\right)$. Неогеновые отложения повсеместно перекрыты четвертичными образованиями различного генезиса [3].

Дагинская свита $\left(\mathrm{N}_{1} \mathrm{dg}\right)$. Отложения залегают на глубинах ниже 2000 м и вскрыты глубоким поисковым бурением. Вскрытый геологический профиль представлен слабосвязанными песками и песчаниками разнозернистыми глинистыми. Песчаники содержат включения мелкой гальки и обуглившегося детрита

Окабыкайская свита $\left(\mathrm{N}_{1} \mathrm{ok}\right)$. Отложения свиты выходят на дневную поверхность вблизи западной границы района работ, на исследованной площади нигде не обнажаются. Представлены переслаиванием песчаных и глинистых разностей при преобладании последних (60-70 \%).

Нижненутовская $\left(\mathrm{N}_{2} \mathrm{nt}_{1}\right)$. Отложения нижненутовской подсвиты обнажаются вблизи западной границы района. Представлены песчано-глинистыми образованиями. Пески обычно плохо отсортированные, косослоистые, часты прослои гравелистых песков, переходящих в гравий с включениями мелкой гальки кремнистого состава. Мощность глинистых прослоек редко превышает 20 м. Мощность подсвиты 600-750 м.

Средне- верхненутовская подсвита $\left(\mathrm{N}_{2} \mathrm{nt}_{2}\right)$. В пределах района развита повсеместно. Она объединяет толщи средне- и грубозернистых песков с прослоями гравелитов, мелкозернистых песчаников и алевролитов и плохоотсортированных разнозернистых песков. Пески обычно серые, желтовато-серые, слоистые, по плоскостям наслоения слюдистые, неотсортированные. Косая слоистость в песках дельтового и прибрежно-морского типов. Алевриты светло-серые, реже желтовато-серые и серые, песчано-глинистые, слоистые и тонкослоистые. Глины встречаются в виде маломощных прослоев. Обычно серого, буро-серого цвета, мягкие, вязкие, зачастую песчаные. Мощность песчаных пластов 2-40 м, реже 80-100 м, глинистых 1-30 м, иногда 50-60 м. Мощность средненутовской подсвиты $1600-1850 \mathrm{M}$.

Четвертичные отложения $(\mathrm{Q})$ развиты повсеместно. Они представлены современными пойменными, биогенными, лагунными и элювиально-делювиальными образованиями.

Аллювиальные отложения 1-ой надпойменной террасы и поймы (a $\left.\mathrm{Q}_{\mathrm{IV}}\right)$ распространены в долине $\mathrm{p}$. Нельбуты и ее притоков. Они представлены песками грубозернистыми и мелкозернистыми с окатанной галькой из отложений нутовской свиты, глинами и алевритами. Мощность данных образований колеблется от 2 до 6 м.

Таблица 1. Эксплуатационные балансовые запасы минеральных подземных вод Дагинского месторождения (м³/сут.)

Table 1. Operating balance reserves of mineral underground waters of the Daginsky deposit $\left(\mathrm{m}^{3} /\right.$ day $)$

\begin{tabular}{|c|c|c|c|c|c|c|}
\hline \multirow{2}{*}{$\begin{array}{l}\text { Категория, } \mathrm{m}^{3} / \mathrm{cyт} \text {. } \\
\text { Category, } \mathrm{m}^{3} / \text { day }\end{array}$} & \multirow[t]{2}{*}{$\mathrm{t},{ }^{\circ} \mathrm{C}$} & \multicolumn{5}{|c|}{$\begin{array}{l}\text { Пределы содержания основных бальнеологических компонентов, мг/дм }{ }^{3} \\
\text { Limits of content of the main balneological components, } \mathrm{mg} / \mathrm{dm}^{3}\end{array}$} \\
\hline & & $\mathrm{M}$ & $\mathrm{H}_{2} \mathrm{SiO}_{3}$ & $\mathrm{Br}$ & B & I \\
\hline $\mathrm{B}+\mathrm{C}_{1}+\mathrm{C}_{2}=2500$ & \multirow{4}{*}{$40-52$} & \multirow{4}{*}{$1200-2460$} & \multirow{4}{*}{$40-47$} & \multirow{4}{*}{ до (to) 6,0} & \multirow{4}{*}{5,1} & \multirow{4}{*}{ до (to) 3,0} \\
\hline $\mathrm{B}=190$ & & & & & & \\
\hline$C_{1}=1495$ & & & & & & \\
\hline $\mathrm{C}_{2}=815$ & & & & & & \\
\hline \multicolumn{7}{|c|}{ в том числе/including: } \\
\hline \multirow{2}{*}{\multicolumn{7}{|c|}{ участок Южный/South section }} \\
\hline $\mathrm{C}_{1}+\mathrm{C}_{2}=1250$ & \multirow{3}{*}{$40-42$} & \multirow{3}{*}{$1200-1900$} & & \multirow{3}{*}{ до (to) 6,0} & \multirow{3}{*}{-} & \multirow{3}{*}{ до 3,0} \\
\hline$C_{1}=864$ & & & \multirow{2}{*}{ до (to) 47} & & & \\
\hline $\mathrm{C}_{2}=386$ & & & & & & \\
\hline \multicolumn{7}{|c|}{ участок Центральный/Central section } \\
\hline $\mathrm{B}+\mathrm{C}_{1}+\mathrm{C}_{2}=1250$ & $51-52$ & 2460 & $40-47$ & - & $4,9-5,1$ & - \\
\hline
\end{tabular}


Лагунно-морские образования ( $\left.{ }_{\mathrm{m}} \mathrm{Q}_{\mathrm{IV}}\right)$ представлены песками мелкозернистыми, илистыми и алевритистыми до грубозернистых. Они развиты вблизи устья р. Нельбуты, где слагают современные морские валы. Мощность голоценовых лагунно-морских отложений колеблется в пределах 2-4 м.

Поверхность четвертичных образований практически повсеместно перекрыта биогенными образованиями ( $\left.\mathrm{Q}_{\mathrm{IV}}\right)$. Мощность торфяников, как правило, составляет 2 м, иногда достигает 3-4 м.

Элювиально-делювиальные отложения (ed $\mathrm{Q}_{\mathrm{IV}}$ ) сплошным чехлом перекрывают неогеновые породы. Для элювия характерно сходство с подстилающими коренными породами, отличие заключается лишь в его большей рыхлости и желтоватой окраске. Мощность этих отложений достигает 3-4 м.

В региональном тектоническом плане месторождение находится в юго-восточной части Северо-Сахалинской наложенной впадины, которая представляет собой одноименный артезианский бассейн [4].

В районе распространены высоконапорные минерализованные подземные воды в глубоких частях гидрогеологического разреза и слабонапорные пресные воды в приповерхностной зоне. Глубокими скважинами (1,5-2,0 км) вскрыты воды с минерализацией 15-20 г/дм³ и температурой $70-80{ }^{\circ} \mathrm{C}$. Возрастание температуры с глубиной подчиняется общему геотермическому градиенту, достигающему $3,5^{\circ} \mathrm{C}$ на $100 \mathrm{M}$.

Интенсивно развитая разрывная тектоника обусловила образование ослабленных зон, по которым напорные минерализованные термальные воды поднимаются на дневную поверхность, образуя локальные очаги разгрузки (Дагинские, Луньские и другие источники) [6]. По мере продвижения вверх происходит понижение температуры подземных вод и разбавление пресными инфильтрационными водами. Поэтому на поверхности температура воды в источниках составляет $20-50{ }^{\circ} \mathrm{C}$, минерализация 2-8 г/дм ${ }^{3}$.

Месторождение сформировано в водоносном комплексе отложений нутовской свиты верхнего неогена. Водовмещающие породы представлены слоистой толщей, состоящей из песков, имеющих высокие фильтрационные свойства, и сабопроницаемых глинистых отложений (рис. 2).

Месторождение имеет очень сложное тектоническое строение, обусловленное наличием нескольких систем разрывных нарушений.

Основная зона гидротермально измененных и передробленных пород, приуроченная к северо-восточному диагональному нарушению, испытывала многократные подвижки и переработку в процессе заложения и развития разрывов северо-западного и меридиональных простираний. Разрывной тектоникой месторождение разбито на три участка: Южный, Центральный и Северный. В каждом из участков свои, отличные от других, условия миграции вод с глубины (рис. 3).

Южный участок изолирован от Центрального и Северного, расположен в районе выхода источников «Мечта», «Молодость». Центральный и Северный участки физической границы не имеют и разделяются по минерализации воды в источниках - около 2 г/дм ${ }^{3}$ на Центральном и более 5 г/дм ${ }^{3}$ - на Северном. На Центральном участке расположены источники «Бегемот», «Пионер», «Центральный», «Патриот», «Партизан». На Северном «Дельфин», «Кальмар». Всего на месторождении наблюдается более 60 восходящих источников термальных минеральных вод (табл. 2).

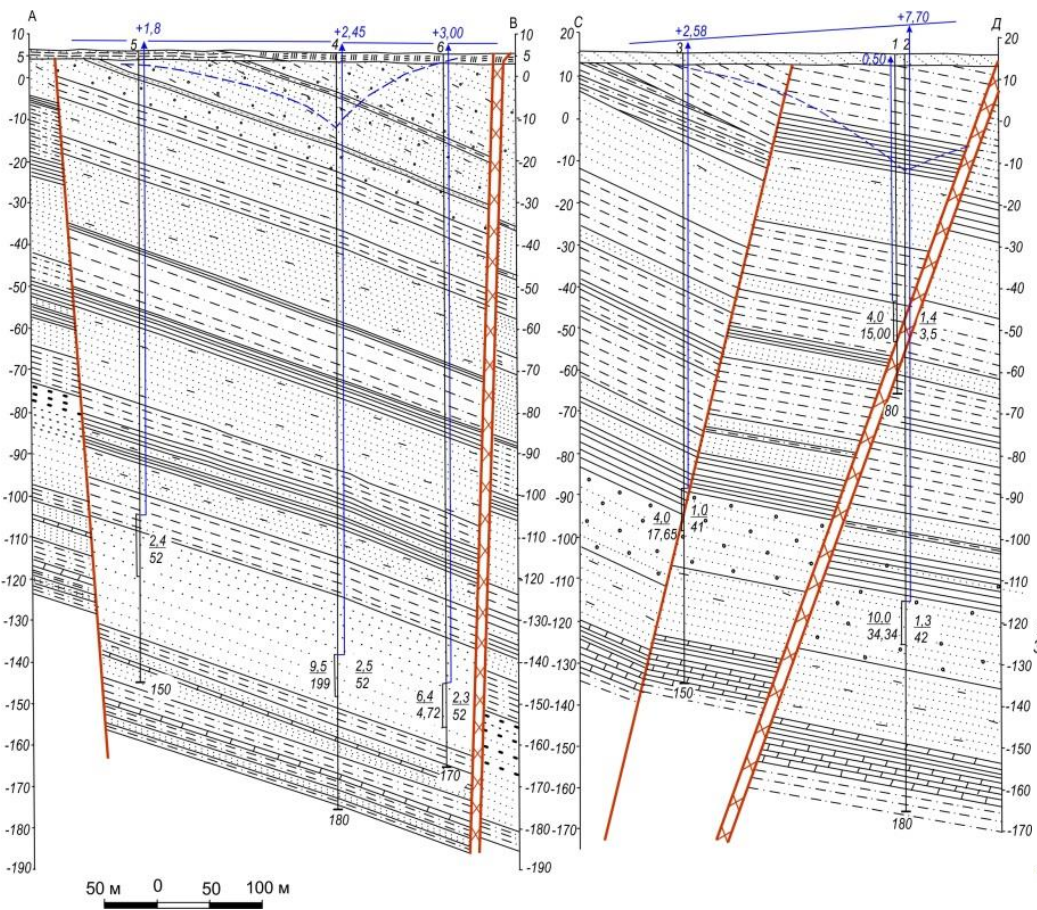

\author{
УСЛОВНЫЕ ОБОЗНАЧЕНИЯ \\ I. Литологический состав \\ mom \\ Песок мелкозернистый \\ Песок средне-крупнозернистый \\ Песок с гравием и галькой \\ Песок глинистый, алевритовый \\ Песчаник \\ Алеврит \\ Глина \\ Разрывные нарушения \\ Зона дробления \\ II. Прочие знаки \\ Скважина. Цифры: \\ внизу - глубина, м; \\ слева: в числителе - дебит, л/с \\ в знаменателе - понижение, м; \\ справа: в числителе - минерализация, г/дм \\ в знаменателе - температура, ${ }^{\circ} \mathrm{C}$ \\ у стрелки - установившийся уровень \\ от поверхности земли, м; \\ прямоугольник - интервал опробования \\ (фильтр) \\ Пьезометрический уровень \\ Депрессионная кривая при опытно- \\ эксплуатационной откачке
}

Pис. 2. Геологический разрез Дагинского месторождения термальных минеральных вод

Fig. 2. Geological section of the Daginsky deposit of thermal mineral waters 
Скважинами изучены Южный и Центральный участки.

На Южном участке при опытно-эксплуатационной откачке из скв. № 2 дебит составил 864 м³/сут при понижении уровня на 34,2 м. Водопроводимость составила 39,5 м²/сут, коэффициент фильтрации - в пределах 1 м/сут.
На Центральном участке фильтрационные свойства пород выше. При опытно-эксплуатационной откачке из скв. № 4 дебит составил $821 \mathrm{~m}^{3} /$ сут при понижении на 19,9 м. Водопроводимость составила 73,5 м²/сут, коэффициент фильтрации - около 3 м/сут.

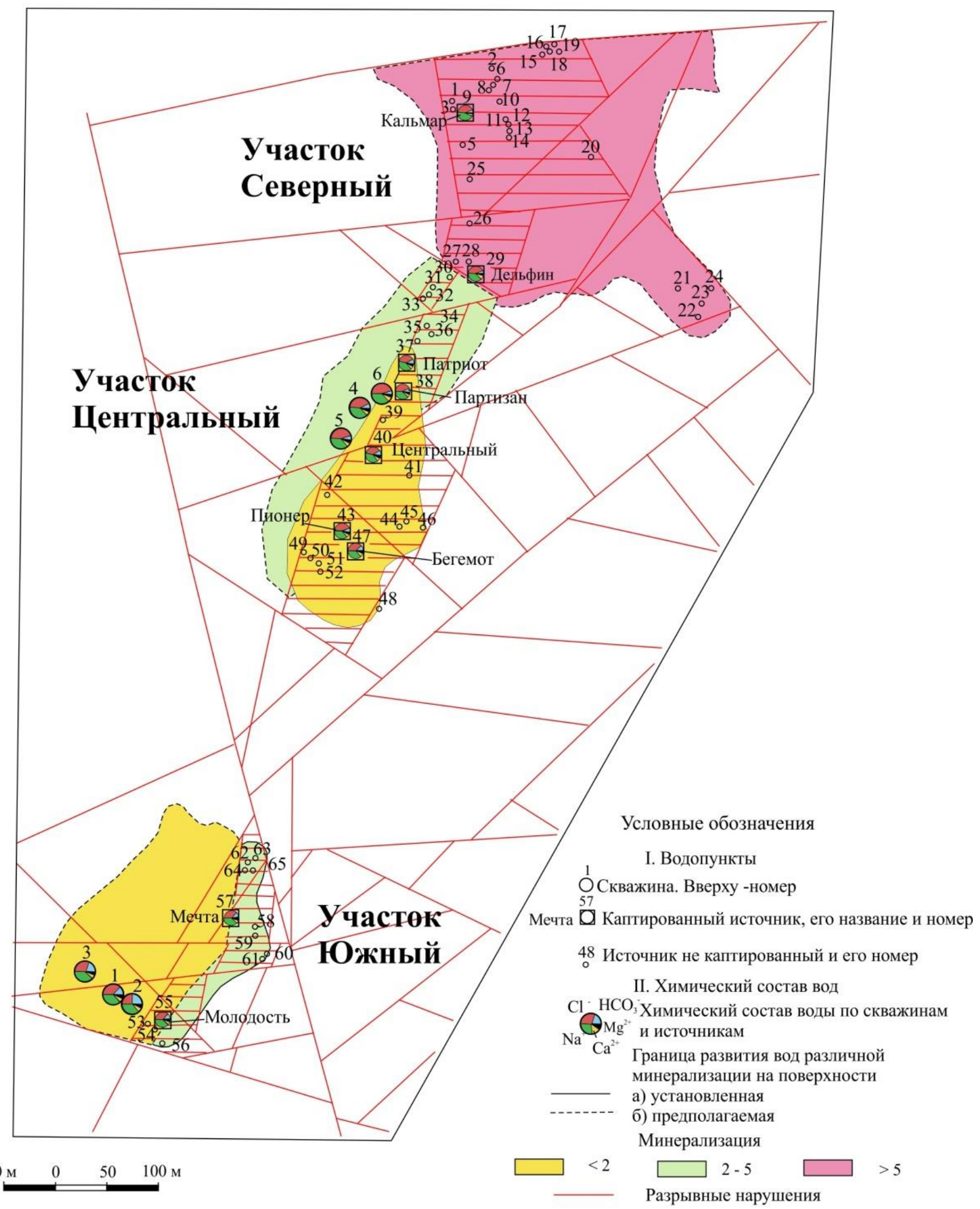

Рис. 3. Схема строения Дагинского месторождения термальных минеральных вод

Fig. 3. Scheme of the structure of the Daginsky deposit of thermal mineral waters 
Известия Томского политехнического университета. Инжиниринг георесурсов. 2020. Т. 331. № 1. 13-26

Сахаров В.А. и др. Условия формирования, современное состояние, перспективы использования (Сахалинская область)

Таблиа 2. Характеристика источников термальных минеральных вод на Дагинском месторождении

Table 2. Characteristics of the sources of thermal mineral waters in the Daginsky field

\begin{tabular}{|c|c|c|c|c|c|c|}
\hline $\begin{array}{l}\text { № на } \\
\text { схеме }\end{array}$ & Название/Title & $\begin{array}{c}\text { Температура } \\
\text { Temperature }\left({ }^{\circ} \mathrm{C}\right)\end{array}$ & $\begin{array}{c}\text { Минерализация, г/дм }{ }^{3} \\
\text { Mineralization, g/dm }\end{array}$ & \multicolumn{3}{|c|}{$\begin{array}{l}\text { Микрокомпоненты } \\
\text { Microcomponents }\end{array}$} \\
\hline 1 & Морской 6/Morskoy 6 & 27 & 5,7 & $\mathrm{~J}$ & - & - \\
\hline 2 & Морской 11/Morskoy 11 & 25 & $\mathrm{H} / \mathrm{c}$ & - & - & $\mathrm{J}-\mathrm{Br}$ \\
\hline 3 & Морской 7/Morskoy 7 & 36 & 5,6 & - & - & - \\
\hline 4 & Морской 5 /Morskoy 5 & 45 & 5,4 & $\mathrm{~J}$ & - & - \\
\hline 5 & Морской 4/Morskoy 4 & 43 & 6,7 & $\mathrm{~J}$ & - & - \\
\hline 6 & Морской 10/Morskoy 10 & 27 & 9,3 & - & - & - \\
\hline 7 & Безымянный/Nameless & 30 & $\mathrm{H} / \mathrm{c}$ & - & - & - \\
\hline 8 & Безымянный/Nameless & 32 & $\mathrm{H} / \mathrm{c}$ & - & - & - \\
\hline 9 & Кальмар/Kalmar & 41 & - & - & - & - \\
\hline 10 & Морской 9/Morskoy 9 & 41 & - & - & - & - \\
\hline 11 & \multirow{14}{*}{ Безымянный/Nameless } & 24 & - & - & - & - \\
\hline 12 & & 31 & - & - & - & - \\
\hline 13 & & 12 & - & - & - & - \\
\hline 14 & & 12 & - & - & - & - \\
\hline 15 & & 22 & - & - & - & - \\
\hline 16 & & 27 & - & - & - & - \\
\hline 17 & & 10 & - & - & - & - \\
\hline 18 & & 26 & - & - & - & - \\
\hline 19 & & 16 & - & - & - & - \\
\hline 20 & & 34 & - & - & - & - \\
\hline 21 & & 25 & - & - & - & - \\
\hline 22 & & 24 & - & - & - & - \\
\hline 23 & & 20 & - & - & - & - \\
\hline 24 & & 21 & - & - & - & - \\
\hline 25 & Морской 3/Morskoy 3 & 41 & 6,5 & - & - & $\mathrm{J}-\mathrm{Br}$ \\
\hline 26 & Безымянный/ Nameless & 41 & - & - & - & $\mathrm{J}-\mathrm{Br}$ \\
\hline 27 & Морской 2/Morskoy 2 & 41 & 6,7 & - & - & $\mathrm{J}-\mathrm{Br}$ \\
\hline 28 & Морской 1/Morskoy1 & 43 & - & - & - & $\mathrm{J}-\mathrm{Br}$ \\
\hline 29 & Дельфин/Delfin & 44 & 8,4 & - & - & $\mathrm{J}-\mathrm{Br}$ \\
\hline 30 & \multirow{4}{*}{ Безымянный/Nameless } & 37 & 2,9 & - & - & - \\
\hline 31 & & 39 & 2,9 & - & - & - \\
\hline 32 & & 36 & - & - & - & - \\
\hline 33 & & 32 & - & - & - & - \\
\hline 34 & Стиральный/Stiralniy & 38 & 2,9 & - & - & - \\
\hline 35 & Питьевой/Pityevoy & 47 & 2,1 & - & - & - \\
\hline 36 & Безымянный/Nameless & 32 & 2,8 & - & - & - \\
\hline 37 & Патриот/Patriot & 42 & 1,6 & - & - & - \\
\hline 38 & Партизан/Partizan & 41 & 1,9 & - & - & - \\
\hline 39 & Дикий/Dikiy & 42 & 1,4 & - & - & - \\
\hline 40 & Центральный/Tsentralny & 52 & 1,6 & - & - & - \\
\hline 41 & Безымянный/Nameless & 20 & 1,2 & - & - & - \\
\hline 42 & Безымянный/Nameless & 45 & 1,6 & - & - & - \\
\hline 43 & Пионер/Pioner & 42 & 1,6 & - & - & - \\
\hline 44 & Безымянный/Nameless & 17 & - & - & - & - \\
\hline 45 & Безымянный/Nameless & 28 & 1,3 & - & - & - \\
\hline 46 & Безымянный/Nameless & 25 & 1,2 & - & - & - \\
\hline 47 & Бегемот/Begemot & 37 & - & - & - & - \\
\hline 48 & \multirow{5}{*}{ Безымянный/Nameless } & 30 & 1,3 & - & - & - \\
\hline 49 & & 36 & - & - & - & - \\
\hline 50 & & 40 & - & - & - & - \\
\hline 51 & & 34 & - & - & - & - \\
\hline 52 & & 37 & - & - & - & - \\
\hline 53 & Питьевой 1/Pityevoy 1 & 36 & 2,9 & - & - & - \\
\hline 54 & Безымянный/Nameless & 42 & 2,7 & - & - & - \\
\hline 55 & Молодость/Molodost & 40 & 2,6 & - & - & - \\
\hline 56 & Безымянный/Nameless & 25 & 2,4 & - & - & - \\
\hline 57 & Мечта/Mechta & 46 & 2,4 & - & - & - \\
\hline 58 & \multirow{5}{*}{ Безымянный/Nameless } & 47 & - & - & - & - \\
\hline $58 \mathrm{a}$ & & 30 & 2,3 & - & - & - \\
\hline 59 & & 38 & 2,5 & - & - & - \\
\hline 60 & & 35 & - & - & - & - \\
\hline 61 & & 35 & 2,3 & - & - & - \\
\hline
\end{tabular}


Общая характеристика гидрогеохимических условий месторождения

Месторождение расположено в пределах одного водоносного комплекса отложений нутовской свиты, представленной многослойной толщей, относится к трещинно-жильным очагового типа [2].

Хлоридные натриевые термальные воды Дагинского месторождения являются морскими седиментационными водами, генетически связаны с нормальными морскими осадочными отложениями в зоне затрудненного водообмена. В этих условиях в восстановительной обстановке формируются метановые воды в результате насыщения подземных вод газами биохимического происхождения [11-20]. Появление азотной составляющей в газовом составе вод, очевидно, связано с тем, что при выходе термоминеральных вод на поверхность происходит смешение их с водами атмосферного и частично морского генезиса. Изменения минерализации в пределах месторождения связано с различными условиями «транспортировки» термоминеральных вод на поверхность.

Накопление кремнекислоты в подземных водах происходит за счет выщелачивания водным раствором силикатов из горных пород, чему благоприятствуют: высокая температура, большое давление, слабощелочная реакция вод, наличие горных пород, содержание $\mathrm{SiO}_{2}$.

В процессе метаморфизации нормальных морских вод в них исчезают ионы $\mathrm{SO}_{4}{ }^{2-}, \mathrm{Ca}^{2+}, \mathrm{Mg}^{2+}$ и накапливаются ионы $\mathrm{HCO}_{3}{ }^{-}$.

Очевидно, в водах имеется дополнительный источник брома, помимо того, который поступил вместе с хлором [12]. Бром дополнительно накапливается в результате разрушения органического вещества, захороняемого вместе с породой. В целом содержание брома коррелируется с минерализацией, оно растет с увеличением последней. Для маломинерализованных вод Южного и Центрального участков при минерализации 2-5 г/дм ${ }^{3}$ концентрация брома не превышает 8 мг/дм³. С увеличением минерализации на Северном участке увеличивается содержание брома (до 37 мг/дм³).

Обогащение подземных вод йодом генетически связано с морскими отложениями, содержащими значительные количества органического вещества. Накоплению йода в водах способствуют также восстановительные условия и щелочная реакция среды. Различное содержание йода на месторождении объясняется, по-видимому, разным количеством глинистого материала на отдельных участках $[8,11]$.

Термальные воды поднимаются к поверхности земли по зонам разрывных нарушений из одного очага (зоны) затрудненного водообмена водоносных комплексов окобыкайских и дагинских отложений. Рассчитанная по $\mathrm{SiO}_{2}$-геотермометру температура теплоносителя на глубине составляет 81-100 ${ }^{\circ} \mathrm{C}$ (табл. 3). Глубина подъема термоминеральных вод составляет 2,7-3,3 км, где их вероятная минерализация, судя по данным глубоких скважин, составляет 15-17 г/дм ${ }^{3}$.

В приповерхностной зоне внедряющиеся минерализованные воды смешиваются с пресными (по составу хлоридно-гидрокарбонатными натриевыми с минерализацией до 0,46 г/дм ${ }^{3}$ ) и образуют «Купола» термоминеральных вод в хорошо проницаемых песчаных пластах. Раз- личные условия миграции глубоких вод и степень их смешения с приповерхностными водами обусловили формирование на месторождении вод двух бальнеологических групп (по классификации В.В. Иванова, Г.А. Невраева, 1964, ГОСТ Р 54316-2011 [5]):

- без «специфических» компонентов,

- йодных, бромных.

Таблица 3. Прогнозная глубинная температура, ${ }^{\circ} \mathrm{C}$, рассчитанная по $\mathrm{SiO}_{2}$-геотермометру

Table 3. Forecast depth temperature, ${ }^{\circ} \mathrm{C}$, calculated using a $\mathrm{SiO}_{2}$-geothermometer

\begin{tabular}{|c|c|}
\hline Источник/Source & Глубинная температура/Deep temperature, ${ }^{\circ} \mathrm{C}$ \\
\hline Бегемот/Begemot & 89,6 \\
\hline Мечта/Mechta & 69,6 \\
\hline Молодость/Molodost & 81,7 \\
\hline Центральный/Tsentralny & 94,7 \\
\hline Пионер/Pioner & 97,8 \\
\hline Партизан/Partizan & 86,6 \\
\hline Патриот/Patriot & 94,7 \\
\hline Дельфин/Delfin & 86,6 \\
\hline Кальмар/Kalmar & 97,8 \\
\hline Скв. № 1/Well no. 1 & 96,8 \\
\hline Скв. № 2/Well no. 2 & 99,9 \\
\hline Скв. № 3/Well no. 3 & 85,6 \\
\hline Скв. № 4/Well no. 4 & 88,6 \\
\hline Скв. № 5/Well no. 5 & 89,6 \\
\hline
\end{tabular}

Само месторождение приурочено к зоне диагонального разрывного нарушения северо-восточного простирания, значительно измененного при формировании нарушений северо-западного и меридионального простирания. Последними месторождение разбито на три участка (рис. 3), в каждом из которых развиты воды, отличающиеся по минерализации.

На Центральном и Южном участках проявляются воды без «специфических» компонентов. Воды теплые и горячие (температура $\left.21-54{ }^{\circ} \mathrm{C}\right)$, слабощелочные ( $\mathrm{pH}-$ 7,9-8,3), хлоридные натриевые, газовый состав - азот, метан. Соленость воды варьирует от 1 до 2,4 г/дм³.

На Южном участке естественные проявления термоминеральных вод (ист. «Молодость» и «Мечта») имеют минерализацию 2,4 г/дм³. Типичная формула ионного состава:

$$
\mathrm{M}_{2,4} \frac{\mathrm{Cl}_{87} \mathrm{HCO}_{3} 12}{(\mathrm{Na}+\mathrm{K}) 93 \mathrm{Ca} 4 \mathrm{Mg} 2} p H 7,4-7,7 .
$$

Температура воды источников $40-41,5^{\circ} \mathrm{C}$. Из микрокомпонентов в незначительных количествах содержится йод $\left(2 \mathrm{мг} /\right.$ дм$\left.^{3}\right)$ и бром $\left(6 \mathrm{мг} /\right.$ дм$\left.^{3}\right)$. Содержание метакремниевой кислоты составляет 28-38 мг/дм³ неологической нормы [6] (50 мг/дм³).

Пробуренными на Южном участке скважинами глубиной до 180 м, вскрыты и опробованы термоминеральные воды того же типа, что и воды поверхностных проявлений. Температура воды на устье скважин при самоизливе $+42{ }^{\circ} \mathrm{C}$. По сравнению с водой источников увеличивается величина $\mathrm{pH}$ и содержание кремнекислоты до 47 мг/дм³, и содержание гидрокарбонат-иона. В незначительных количествах содержится йод и бром (I $0,8 \mathrm{мг} /$ дм$^{3}, \mathrm{Br}-1,4 \mathrm{мг} /$ дм³ $^{3}$. В воде практически отсутствуют нитраты и нитриты, железо. В небольших количествах (до 2,1 мг/дм³) отмечено наличие аммония. 
Типичная формула ионного состава имеет вид:

$$
\mathrm{M}_{1,7} \frac{\mathrm{Cl} 47 \mathrm{HCO}_{3} 45 \mathrm{CO}_{3} 8}{(\mathrm{Na}+\mathrm{K}) 98 \mathrm{Ca}} p H 8,7 \text {. }
$$

При проведении опытно-эксплуатационной откачки из скв. 2 химический и микрокомпонентный состав оставался постоянным, как и состав воды источников Южного участка.

На Центральном участке источниками выведены на поверхность термоминеральные воды без «специфических» компонентов с температурой $38-51{ }^{\circ} \mathrm{C}$ и минерализацией до 2 г/дм³ (преимущественно 1,1-1,7 г/дм³).

Воды слабощелочные. Концентрация метакремниевой кислоты составляет 38-42 мг/дм³ (до $51 \mathrm{mг} /$ дм $^{3}$, ист. «Центральный»).

Типичная формула ионного состава имеет вид:

$$
\mathrm{M}_{1,7} \frac{\mathrm{Cl}(85-90) \mathrm{HCO}_{3}(15-10)}{(\mathrm{Na}+\mathrm{K}) 93 \mathrm{Ca} 6} p H 7,7-8,0 .
$$

Bсе источники Центрального участка расположены в заболоченной низине и во время длительных дождей и интенсивного снеготаяния температура и минерализация их вод снижается, хотя тип воды остается постоянным. Стабильным остается только состав источника «Центральный», который изолирован от болотных вод.

В многолетнем разрезе состав вод Центрального участка постоянный. Температура изменяется в пределах $1-3{ }^{\circ} \mathrm{C}$.

Подземные воды на Центральном участке изучены скважинами № 4-6 до глубины 180 м. На поверхность выведены воды без «специфических» компонентов с минерализацией 2,1-2,5 г/дм³.Отмечается содержание в небольших количествах йода -2 мг/дм ${ }^{3}$, брома -5 мг/дм ${ }^{3}$ Температура вод на устье скважин составила $51-52{ }^{\circ} \mathrm{C}$. В ходе опытно-эксплуатационной откачки состав воды и температура оставались стабильными.

Типичная формула ионного состава:

$$
\mathrm{M}_{2,5} \frac{\mathrm{Cl} 88 \mathrm{HCO}_{3} 10 \mathrm{CO}_{3} 2}{(\mathrm{Na}+\mathrm{K}) 92 \mathrm{Ca} 3 \mathrm{Mg} 1} p H 7,9-8,0 .
$$

На Северном участке воды, согласно ГОСТ Р 543162011, относятся к группе йодных, бромных. Проявления наблюдаются в виде восходящих источников, получивших общее название «Морские» (типичные представители «Дельфин» и «Кальмар»). Химический состав воды хлоридный натриевый, минерализация 5,4-9,0 г/дм³ , содержание йода 5,0-9,2 мг/дм³, брома 18-37 мг/дм³, метакремниевой кислоты $18-34$ мг/дм 3 , $\mathrm{pH}-7,9-8,1$. Температура вод в источниках $40-42{ }^{\circ} \mathrm{C}$.

Типичная формула ионного состава:

$$
\mathrm{M} 5,5 \frac{\mathrm{Cl}_{9} 97 \mathrm{HCO}_{3} 3}{(\mathrm{Na}+\mathrm{K}) 85 \mathrm{Ca} 10 \mathrm{Mg} 2} p H 7,9-8,1 .
$$

Источники подвержены затоплению. Во время высоких приливов на море, когда источники заливаются морской водой, возрастает минерализация воды, содержание кремнекислоты уменьшается как и температура воды. Примерно через 1,5 часа после отлива свойства воды полностью восстанавливаются (по режимным наблюдениям на источнике «Дельфин»). От затопления «мор- ских» источников легко защититься, если их каптировать сооружениями с краями, выше поверхности земли на 0,8-1,0 м. В многолетнем разрезе тип воды не изменяется.

На Северном участке скважины не бурились, подземные воды не изучались.

По составу свободно выделяющегося газа воды Дагинских источников являются метановыми и азотнометановыми. В составе растворенного газа преобладают азот и углекислота. Сероводород отсутствует. Наличие в составе газа свободного водорода указывает на его глубинное происхождение.

Микрокомпонентный состав вод исключительно бедный.

Специальными анализами установлено отсутствие элементов, оказывающих вредное воздействие на организм человека. Поскольку в настоящее время отсутствуют запретительные критерии для минеральных вод, используемых при бальнеолечении для наружного применения, предельно допустимые концентрации вредных компонентов сравнивались в соответствии с ГОСТ P 54316-2011 [5] для питьевых лечебных и лечебностоловых вод. Максимальное содержание токсичных компонентов на Дагинском месторождении приведено в табл. 4.

Таблица 4. Данные о гостируемых содержаниях токсичных компонентов в водах Дагинского месторожде-

\begin{tabular}{|c|c|c|}
\hline $\begin{array}{l}\text { Компоненты } \\
\text { Components }\end{array}$ & 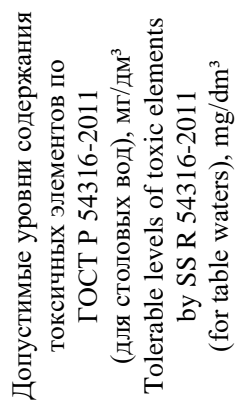 & 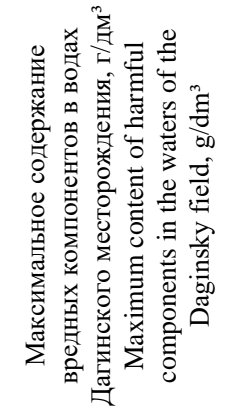 \\
\hline Барий/Barium & 1,0 & 0,6 \\
\hline Кадмий/Cadmium & 0,003 & H.o. / not detected \\
\hline Медь/Copper & 1,0 & 0,02 \\
\hline Мышьяк/Arsenic & 0,05 & H.o. / not detected \\
\hline Никель/Nickel & 0,02 & 0,006 \\
\hline Нитраты/Nitrates & 50,0 & 4,0 \\
\hline Нитриты/Nitrites & 0,1 & H.c. /no information \\
\hline Ртуть/Mercury & 0,001 & H.c. /no information \\
\hline Селен/Selenium & 0,01 & 0,0002 \\
\hline Selenium/Selenium & 0,01 & 0,008 \\
\hline Стронций/Strontium & 7,0 & 3,4 \\
\hline Сурьма/Antimony & 0,005 & H.o. / not detected \\
\hline Xром/Chromium & 0,05 & 0,012 \\
\hline Цианиды/Cyanides & 0,07 & H.c. $/$ no information \\
\hline
\end{tabular}
ния

Table 4. Data on the accommodated contents of toxic components in the waters of the Daginsky deposit

Примечание: н.о. - не обнаружено (not detected); н.c. - нет сведений (no information).

Из таблицы видно, что содержание токсичных веществ, которые были определены в термоминеральных водах Дагинского месторождения, ниже допустимых уровней. Отметим, что анализы выполнялись в 1991 г. и ранее. Необходимо провести гидрохимическое опробо- 
вание источников с соблюдением требований актуальных руководящих документов.

В ненарушенных условиях бактериологические показатели воды в источниках и скважинах соответствуют санитарным нормам.

\section{Бальнеологическое значение}

Согласно ГОСТ Р 54316-2011 [5], по химическому составу воды Северного участка наиболее близки к воде Талицкого месторождения, Свердловская область. Группа ХХХг: вода среднеминерализованная, хлоридная натриевая, бромная, йодная. Лечебная. Тип Талицкий. Медицинские показатели по внутреннему применению: B.2.1*, B.2.3, B.4, B.5, B.7.

Воды Центрального и Южного участков наиболее близки водам Обуховского месторождения, Свердловской области. Группа XXVIII: вода слабоминерализованная, гидрокарбонатно-хлоридная натриевая. Лечебностоловая. Тип Обуховский. Медицинские показатели по применению: В.1, В.2.1, В.2.2, В.2.3., В.3, В.4, В.5, В.6, B.7, B.8, B.9.

*ГОСТ Р 54316-2011. Приложение В

Перечень медицинских показаний по применению (внутреннему) минеральных вод.

В.1 Болезни пищевода (эзофагит, гастроэзофагеальная рефлюксная болезнь).

В.2 Хронический гастрит:

В.2.1 с нормальной секреторной функцией желудка;

В.2.2 с повышенной секреторной функцией желудка;

В.2.3 с пониженной секреторной функцией желудка;

В.3 Язвенная болезнь желудка и 12-перстной кишки.

В.4 Болезни кишечника (синдром раздраженного кишечника, дискинезия кишечника).

В.5 Болезни печени, желудочного пузыря и желчевыводящих путей.

В.6 Болезни поджелудочной железы (хронический панкреатит).

В.7 Нарушение органов пищеварения после оперативных вмешательств по поводу язвенной болезни желудка, постхолецистэктомические синдромы.

В.8 Болезни обмена веществ (сахарный диабет, ожирение, нарушение солевого и липидного обмена).

В.9 Болезни мочевыводящих путей (хронический пиелонефрит, мочекаменная болезнь, хронический цистит, уретрит).

До настоящего времени официальные сведения о бальнеологических свойствах воды Дагинских источников при наружном применении отсутствуют. По отзывам пользователей, считается, что вода в источниках Северного и Центрального участок обладает положительным эффектом при лечении кожных болезней, при функциональных нарушениях центральной нервной системы, лечении органов пищеварения, в эстетической медицине, косметологии. Вода из источников Южного участка дает положительный эффект при лечении кожных заболеваний, заболеваний опорно-двигательного аппарата, гинекологических патологий.

\section{Современное состояние}

Дагинские геотермальные источники, известные под названием «Горячие Ключи», в настоящее время используются «диким образом». Исключение составляют две организации ООО «Бытовик» и «Лесхоз», которые имеют закрытые бассейны (однако использование термальных вод весьма незначительно).

Воды используются в основном для принятия ванн на источниках. На сегодняшний день на месторождении остался только один благоустроенный павильон в относительно удовлетворительном состоянии «Патриот» (рис. 4), остальные источники руками энтузиастов оборудованы самодельными укрытиями (рис. 5-10).

На тропе от пос. Горячие ключи к источникам расположена скважина, пробуренная при разведке месторождения, вода из которой населением используется в качестве лечебной питьевой, а также в гигиенических целях (рис. 11).

В целом, не смотря на, мягко говоря, неприглядное санитарное и техническое состояние, Дагинские источники весьма популярны у населения Сахалинской области. Современная посещаемость источников оценена нами в летний период в 300 человек в сутки без учета упомянутых домов отдыха. По опросным данным, большое количество людей регулярно (часто ежегодно) посещают Дагинские источники для поправки здоровья. Вместе с тем многих отпугивает неблагополучное санитарное состояние источников и бытовые условия. Так как используются лишь 6 источников, нагрузка на один источник составляет около 50 человек в день. В этом случае природа справляется со сложившейся нагрузкой, так как на протяжении нескольких десятков лет источники находится в стабильном состоянии. При восстановлении заброшенных известных источников количество посещений можно безболезненно увеличить как минимум в два раза. Отметим, что указанное количество посещений относится к летнему периоду, т. к. большое количество приезжих проживает в палатках. Количество посещений зимой ограничивается количеством мест в местных гостиницах и съемных помещениях, а также плохой доступностью самих источников.
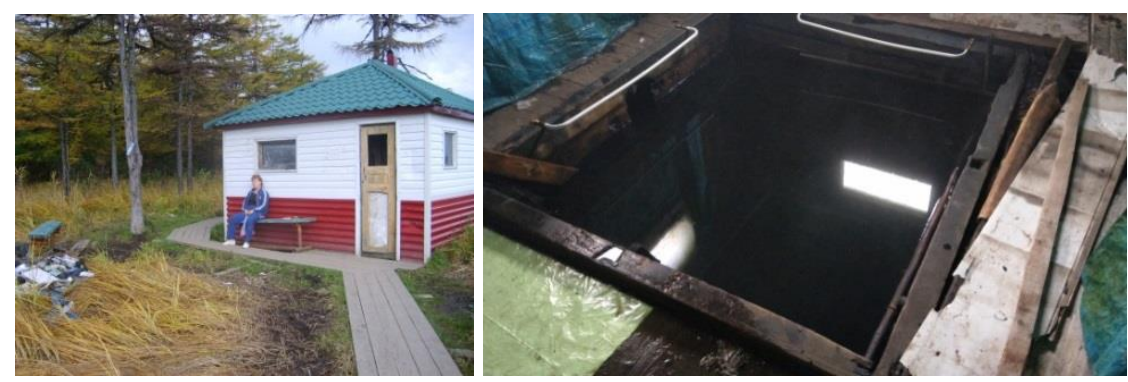

Pис. 4. Источник «Патриот»

Fig. 4. Source «Patriot» 
Известия Томского политехнического университета. Инжиниринг георесурсов. 2020. Т. 331. № 1. 13-26 Сахаров В.А. и др. Условия формирования, современное состояние, перспективы использования (Сахалинская область)
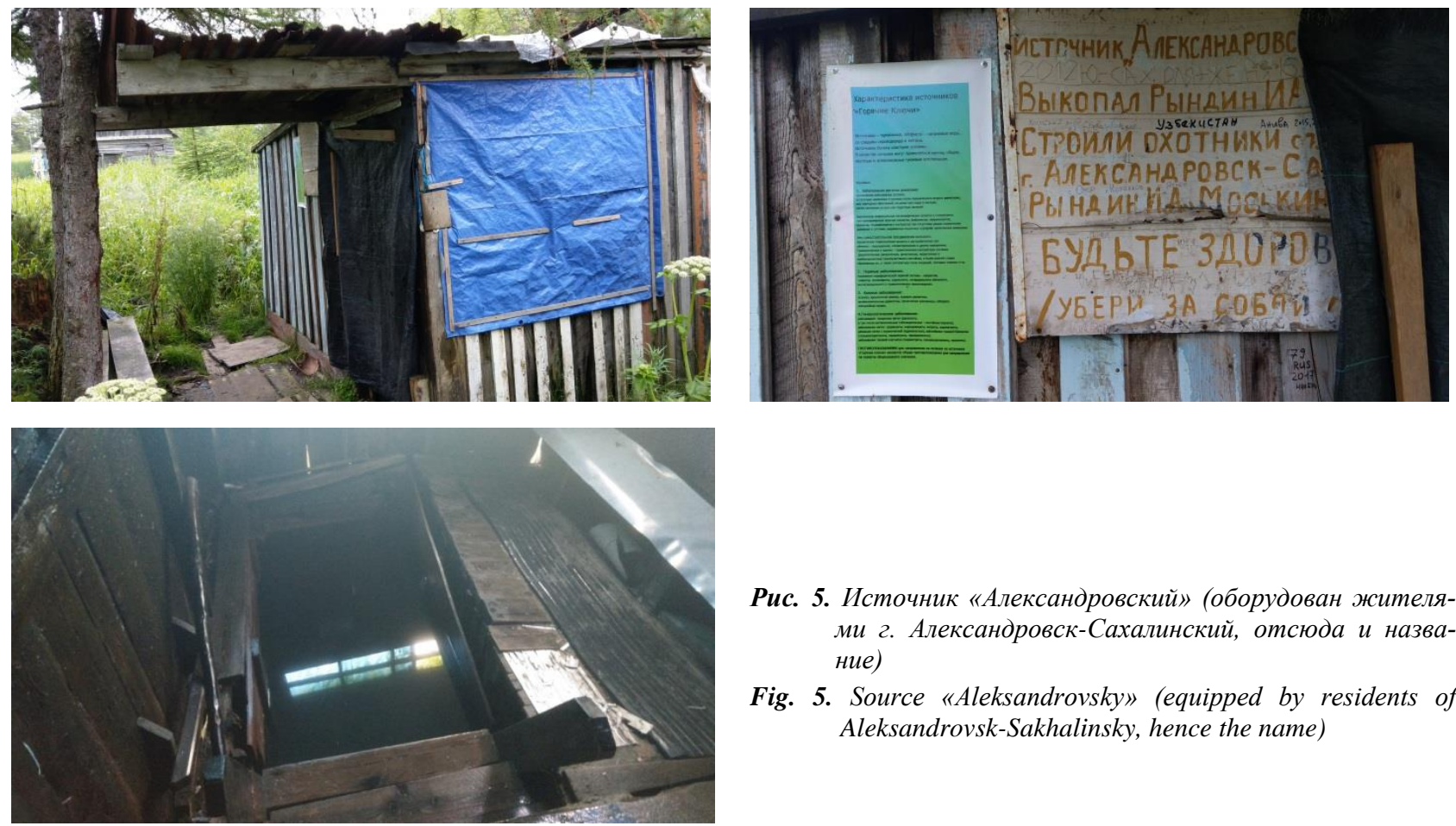

Рис. 5. Источник «Александровский» (оборудован жителями г. Александровск-Сахалинский, отсюда и название)

Fig. 5. Source "Aleksandrovsky» (equipped by residents of Aleksandrovsk-Sakhalinsky, hence the name
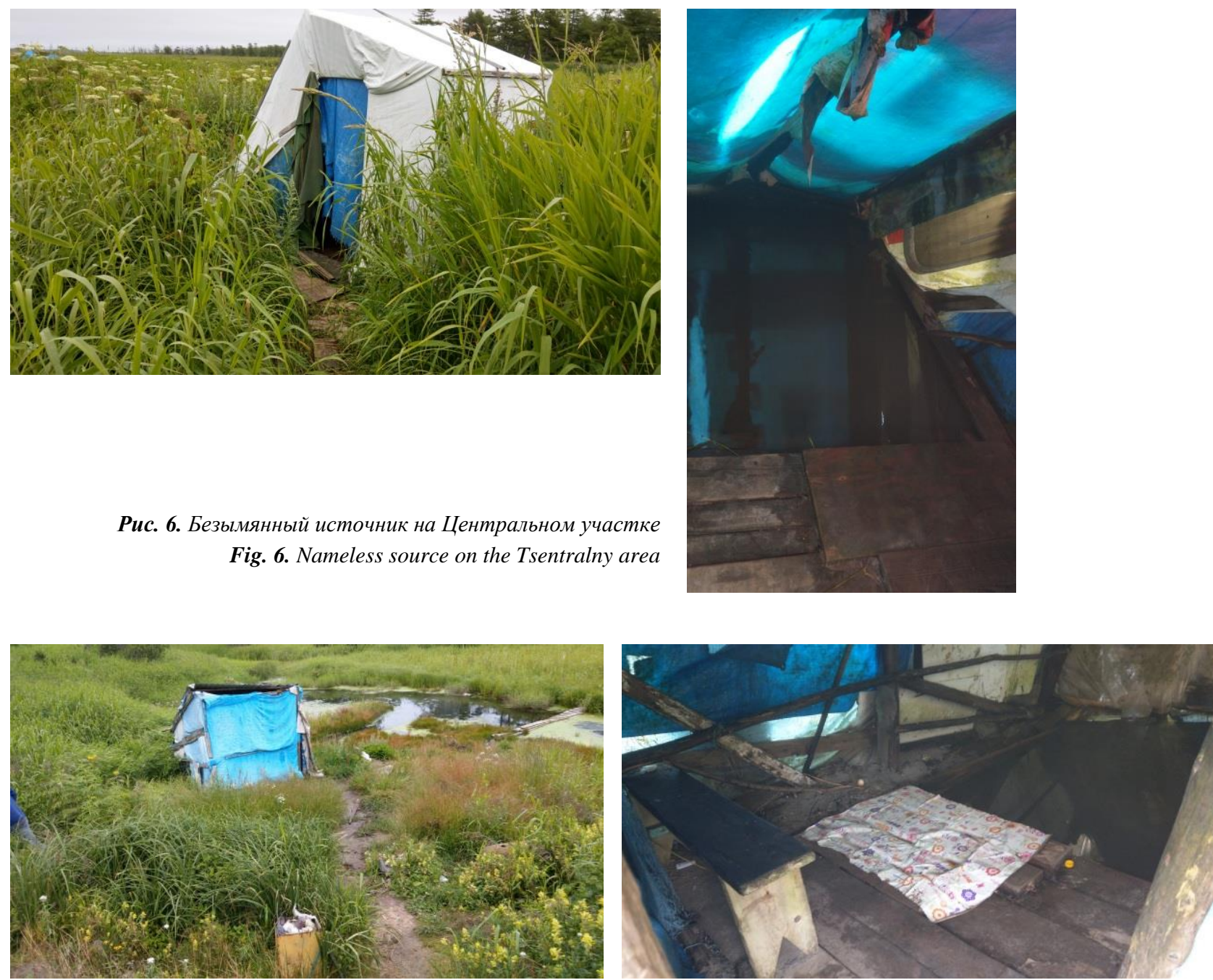

Puc. 7. Источник «Мечта»

Fig. 7. Source «Mechta» 
Известия Томского политехнического университета. Инжиниринг георесурсов. 2020. Т. 331. № 1. 13-26
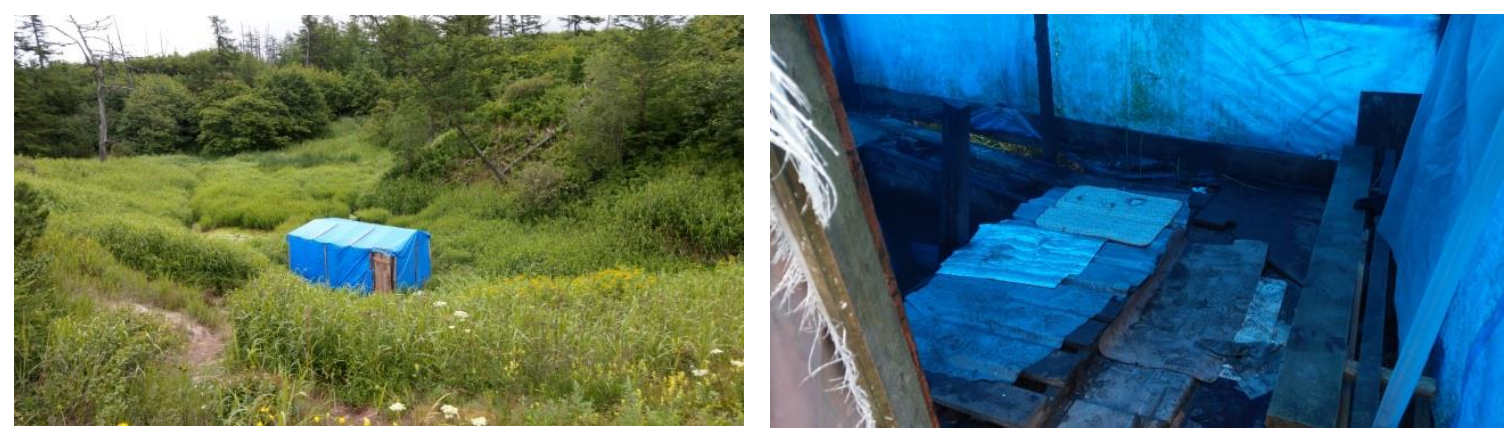

Pис. 8. Источник «Молодость»

Fig. 8. Source «Molodost»
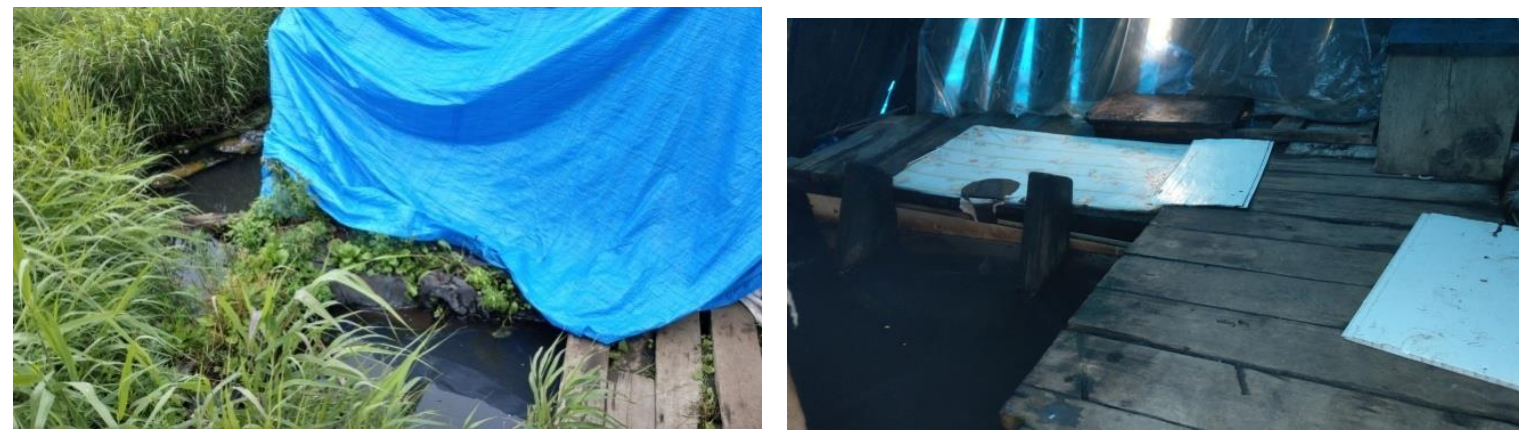

Pис. 9. Источник «Партизан»

Fig. 9. Source «Partizan»

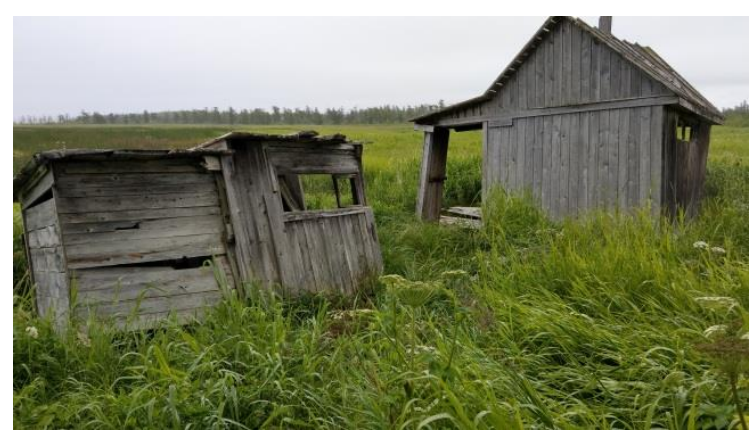

Рис. 10. Источники «Кальмар» (слева), «Трепанг» (аварийные не используются)

Fig. 10. Sources «Kalmar» (left), "Trepang» (emergency ones are not used)

В случае применения принудительной добычи термальных вод с помощью скважин, количество посещений может быть увеличено в разы.

\section{Рекомендации}

Термальные минеральные воды месторождения обладают очень высокой биологической активностью. Бесконтрольное применение вод вместо лечебного может привести к негативному эффекту. Известны случаи летальных исходов после чрезмерно длительного принятия ванн в источниках. Необходимо провести всестороннее исследование бальнеологических свойств вод различных источников и разработать рекомендации по методике их применения.

Также необходимо организовать мониторинг источников с целью определения времени восстановления воды после посещения и разработать режим приема ванн.

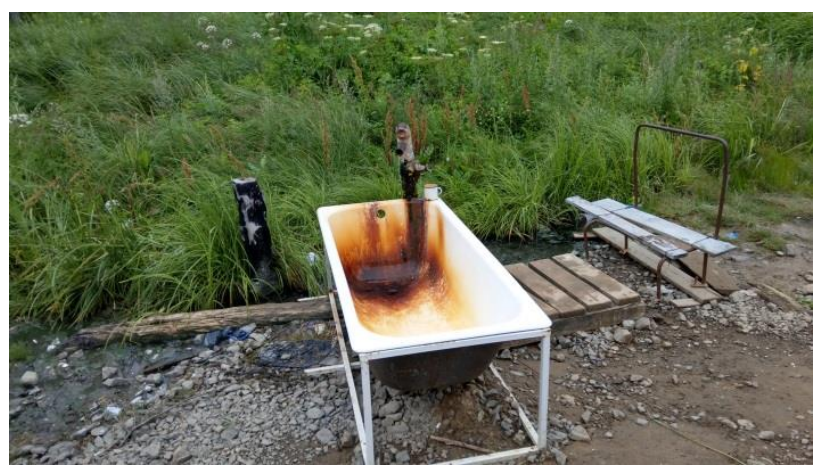

Pис. 11. Заброшенная скважина

Fig. 11. Abandoned borehole

Организовать эксплуатацию источников в соответствии с «Правилами разработки месторождений минеральных вод и лечебных грязей».

\section{Заключение}

Многолетней эксплуатацией Дагинского месторождения доказана высокая бальнеологическая эффективность термальных минеральных вод.

Месторождение сформировано путем смешения глубинных горячих минерализованных вод с приповерхностными холодными и пресными подземными водами. Разрывной тектоникой разбито на три участка. Подземные воды напорные, уровни устанавливаются на отметках «+»4-«+»7,7 м. Фильтрационные свойства водовмещающих пород достаточно высокие, удельные дебиты скважин составили 25-41 м³/сут*. На участке месторождения наблюдается более 60 восходящих источников термоминеральных вод. 
Воды горячие слабо- и среднеминерализованные, хлоридные натриевые, бромные, йодные (Северный участок) и гидрокарбонатно-хлоридные натриевые (Центральный и Южный участки). Балансовые эксплуатационные запасы утверждены по категориям $\mathrm{B}+\mathrm{C}_{1}+\mathrm{C}_{2}$ в количестве $2500 \mathrm{M}^{3} /$ сут.

Согласно ГОСТ Р 54316-2011, воды в источниках обладают широким спектром медицинских показателей по внутреннему применению. Кроме того, многолетний опыт (несколько десятков лет) свидетельствует о том, что воды дают положительный эффект и при наружном применении.

\section{СПИСОК ЛИТЕРАТУРЫ}

1. Бровко П.Ф., Дзен Г.Н., Малюгин А.В. Рекреационные ресурсы о. Сахалин // Сборник материалов Всесоюзной молодежной школыконференции, посвященной 25 -летию кафедры физической географии и геоморфологии им. И.Н. Арчикова и 50-летию Федерального государственного бюджетного образовательного учреждения высшего образования «Чувашский государственный университет им. И.Н. Ульянова». - Чебоксары: ИД «Среда», 2017. - С. 190-196.

2. Вартанян Г.С., Яроцкий Л.А. Поиски, разведка и оценка эксплуатационных запасов месторождений минеральных вод. - М. Недра, 1972. - $126 \mathrm{c}$.

3. Геология СССР. Т. ХХХІІІ. Остров Сахалин. - М.: Недра, 1970. 432 c.

4. Гидрогеология СССР. Т. XXIV. Остров Сахалин. - М.: Недра, 1972. $-343 \mathrm{c}$

5. ГОСТ Р 54316-2011 Воды минеральные природные питьевые. М.: Стандартинформ, 2011. - 33 с.

6. Жарков Р.В. Геохимические особенности и перспективы использования термальных вод острова Сахалин // XXII Совещание по подземным водам Сибири и Дальнего Востока с международным участием. - Новосибирск: Новосибирский национальный исследовательский государственный университет, 2018. - С. 204-207.

7. Завгорудько М.С., Завгорудько В.Н., Шаталова И.Г. Рекреационный ресурс Дагинского месторождения термальных минеральных вод // Актуальные вопросы современной медицины: Материалы 70-й итоговой научной конференции молодых ученых и студентов. - Хабаровск: Дальневосточный государственный медицинский университет, 2013. - С. 117-119.

8. Посохов Е.В., Толстихин Н.И. Минеральные воды: лечебные промышленные, энергетические. - Л.: Недра, 1977. - 240 с.

9. Розен Б.Я. Геохимия брома и йода. - М.: Недра, 1970. - 144 с

10. Суслова К.И., Чернов В.А. Дагинские термальные источники как туристический ресурс Сахалинской области // Развитие медицинской реабилитации на Дальнем Востоке. - Хабаровск: Дальневосточный государственный медицинский университет, 2016. - C. 68-70.
В настоящее время месторождение эксплуатируется «диким образом». Воды используются в основном для принятия ванн на источниках. Посещаемость источников в летнее время достигает 300 чел./день. В зимний период посещение источников затруднено. Имеются хорошие перспективы для многократного увеличения количества посещений без капитальных затрат на разведку месторождения.

Благодарности. Использованы материаль Сахалинской гидрогеологической экспедииии. B работе участвовали А.И. Бондарев, И.Г. Завадский, О.А. Кутузов, И.В. Леонов, А.Ф. Прядко, Т.С. Розорителева, Н.Н. Самсонова, Н.Э. Точилин. Результаты получены в рамках выполнения государственного задания Минобрнауки РФ: 5.9560.2017/8.9.

11. Филатов Д.Г. Бромные подземные минеральные воды: генезис и бальнеологические свойства // Вестник Воронежского государственного университета, серия: геология. - 2012. - № 2. - С. 229-235.

12. Alcalá F.J., Custodio E. Using the $\mathrm{Cl} / \mathrm{Br}$ ratio as a tracer to identify the origin of salinity in aquifers in Spain and Portugal // Journal of Hydrology. - 2008. - № 359. - P. 189-207.

13. Barut I.F., Erdogan N., Basak E. Hydrogeochemical evaluation of western Anatolian mineral waters // Environmental Geology. 2004. - V. 45. - № 4. - P. 494-503.

14. Grasby S.E., Hutcheon I., Krouse H.R. The influence of water-rock interaction on the chemistry of thermal springs in western Canada // Applied Geochemistry. - 2000. - V. 15. - № 4. - C. 439-454.

15. Evaluation of the effect of balneotherapy in patients with osteoarthritis of the hands: a randomized controlled single-blind follow-up study / K. Horváth, Á. Kulisch, A. Németh, T. Bender // Clinical Rehabilitation. - 2012. - V. 26. - № 5. - P. 431-441.

16. Kralj P., Kralj P. Thermal and mineral waters in north-eastern Slovenia // Environmental Geology. - 2000. - V. 39. - № 5. - P. 0488-0500.

17. Melioris L. Mineral and thermal waters of the Ipelská Pahorkatina hillyland // Environmental Geology. - 2000. - V. 39. - № 5. P. 448-462.

18. Formation of chemical composition of injection-type mineral water deposits as exemplified by chapaevskoye field in Korsakov district of Sakhalin region / V.A. Sakharov, O.A. Morozova, E.N. Vypryzhkin, I Ken Khi, H.S. Poliak // Periódico TchêQuími. - 2019. - V. 16. № 31. - P. 457-471.

19. Tarcan G., Gemici U. Water geochemistry of the seferihisar geothermal aria, Izmir Turkey // Journal of Volcanology and Geothermal Research. - 2003. - V. 126. - № 3-4. - P. 225-242.

20. Mineral and thermal waters of Serbia: multivariate statistical approach to hydrochemical cyaracterization / M. Todorović, J. Štrbački, M. Ćuk, J. Andrijašević, J. Šišović, P. Papić // Environmental Earth Sciences. - 2016. - P. 81-95.

Поступила 28.01.2019 2.

\section{Информация об авторах}

Сахаров В.А., кандидат геолого-минералогических наук, заведующий лабораторией Сахалинского государственного университета.

Ильин В.В., старший преподаватель кафедры строительства Технического нефтегазового института Сахалинского государственного университета.

Морозова О.A., ведущий инженер Сахалинского государственного университета.

Bыпряжкин $\boldsymbol{E . H . , ~ в е д у щ и и ̆ ~ и н ж е н е р ~ С а х а л и н с к о г о ~ г о с у д а р с т в е н н о г о ~ у н и в е р с и т е т а . ~}$

$\boldsymbol{И} \boldsymbol{\kappa} \boldsymbol{e \boldsymbol { X }} \boldsymbol{\boldsymbol { u }}$, ведущий инженер Сахалинского государственного университета.

Гоголева И.В., стажер Сахалинского государственного университета. 
UDC 553.7

\title{
DAGINSKY DEPOSIT OF THERMAL MINERAL WATERS. FORMATION CONDITIONS, CURRENT STATE, PROSPECTS FOR USE (SAKHALIN REGION)
}

\author{
Valeriy A. Sakharov ${ }^{1}$, \\ sakhsakh@yandex.ru \\ Vladimir V. llin 1 , \\ vladimirilyin7@gmail.com \\ Olga A. Morozova ${ }^{1}$, \\ sgi84@mail.ru \\ Evgeny N. Vypryazhkin ${ }^{1}$, \\ e_vipryashken@mail.ru \\ I Ken Khi', Sakhgu@list.ru \\ Irina V. Gogoleva ${ }^{1}$, \\ risha.89@mail.ru \\ 1 Sakhalin State University, \\ 68, Pogranichnaya street, Yuzhno-Sakhalinsk, 693008, Russia.
}

The relevance of the research is caused by the need to expand the use of the resource base of mineral waters for balneological purposes, close to the consumer, assess the therapeutic properties of mineral waters based on a study of their operating experience and compliance with the requirements of current guidance documents. The development of this direction will allow increasing the volume and spectrum of therapeutic and preventive services using local natural mineral waters while minimizing the capital expenditures for geological exploration.

The aim of the research is to study the structure, current state and operating experience of the Daginsky thermal mineral water field (Sakhalin Region), to assess the prospects for expanding balneological and tourist services, to develop recommendations for industrial development of the field.

Objects: mineral thermal waters, their properties and conditions of distribution on the earth's surface and in the hydrogeological section.

Methods: study of stock and archive documents on geological structure and hydrogeological conditions of the study area, a field survey of the current state of the field, hydrochemical testing of individual sources, a survey of mineral water consumers.

Results. The paper introduces the geological and hydrogeological characteristics of the field of thermal mineral waters. The balneological properties of the waters in different parts of the field were determined in accordance with the relevant guidelines. The present state of use of thermal mineral waters is presented. The authors have developed the recommendations for field operation.

Findings. The long-term operation of the Daginsky field proves high balneological efficiency of thermal mineral waters. The field is formed by mixing deep hot mineralized waters with near-surface cold and fresh groundwater. Explosive tectonics field is divided into three sections. More than 60 ascending sources of thermomineral waters are observed on the site of the field. The waters are hot, weakly and moderately mineralized, sodium chloride, bromine, iodine (Northern part) and sodium bicarbonate-sodium (Central and Southern). Balance operational reserves are approved for categories $B+C_{1}+C_{2}$ in the amount of $2500 \mathrm{~m}^{3} /$ day. Water in the sources have a wide range of medical indicators for use. Currently, the field is exploited "wildly». Waters are used primarily for bathing at the springs. Attendance sources in the summer reaches 300 people/day. In winter, visiting the sources is difficult. There are good prospects for a multiple increase in the number of visits without the capital expenditure on exploration of the field. Thermal mineral waters of the deposit have a very high biological activity. Uncontrolled use of water instead of therapeutic, can lead to a negative effect. There are cases of deaths after excessively long baths in the sources. It is necessary to conduct a comprehensive study of the balneological properties of waters of various sources and to develop recommendations on the method of their use. It is also necessary to organize monitoring of sources in order to determine the time of water recovery after the visit and to develop a mode of bathing.

\section{Key words:}

Thermal mineral waters, thermal mineral source, balneological properties of water, geothermal gradient, discontinuous tectonics.

The authors appreciate the specialists of the Sakhalin hydrogeological company whose data and reports were applied in the article: A.I. Bondarev, I.G. Zavadsky, O.A. Kutuzov, I.V. Leonov, A.F. Pryadko., T.S. Rozoriteleva, N.N. Samsonova, N.E. Tochilin. The results were obtained in the framework of the fulfillment of the state task of the Ministry of Education and Science of the Russian Federation: 5.9560.2017/8.9.

\section{REFERENCES}

1. Brovko P.F., Dzen G.N., Malyugin A.V. Rekreatsionnye resursy o. Sakhalin [Recreational resources of Sakhalin]. Sbornik materialov Vsesoyuznoy molodezhnoy shkoly-konferentsii, posvyashchennoy 25-letiyu kafedry fizicheskoy geografii $i$ geomorfologii im. I.N. Archikova i 50-letiyu Chuvashskogo gosudarstvennogo universiteta im. I.N. Ulyanova [Collection of materials of the All-Union Youth School Conference dedicated to the $25^{\text {th }}$ anniversary of the department of I.N. Archikov physical geography and geomorphology and the $50^{\text {th }}$ anniversary of Chuvash State University named after I.N. Ulyanov]. Cheboksary, Sreda Publ. house, 2017. pp. 190-196.

2. Vartanyan G.S., Yarotsky L.A. Poiski, razvedka $i$ otsenka ekspluatatsionnykh zapasov mestorozhdeny mineralnykh vod [Prospecting, exploration and evaluation of the operational reserves of mineral water deposits]. Moscow, Nedra Publ., 1972. $126 \mathrm{p}$.

3. Geologiya SSSR. T. 33. Ostrov Sakhalin [Geology of the USSR. Vol. 33. Sakhalin Island]. Moscow, Nedra Publ., 1970. 431 p. 
4. Gidrogeologiya SSSR. T. XXIV. Ostrov Sakhalin [Hydrogeology of the USSR. Vol. XXIV. Sakhalin island]. Moscow, Nedra Publ., 1972. $343 \mathrm{p}$.

5. GOST R 54316-2011 Vody mineralnye prirodnye pityevye [State Standard R 54316-2011 Natural mineral drinking water]. Moscow, Standartinform Publ., 2011. 33 p.

6. Zharkov R.V. Geokhimicheskie osobennosri i perspekrivy ispolzovaniya termalnykh vod ostrova Sakhalin Geochemical features and prospects for the use of thermal waters of Sakhalin Island]. XXII Soveshchanie po podzemnym vodam Sibiri i Dalnego Vosroka s mezhdunarodnym uchastiem [XXII Conference on Groundwater of Siberia and the Far East with international participation]. Novosibirsk, NNIGU Publ., 2018. pp. 204-207.

7. Zavgorudko M.S., Zavgorudko V.N., Shatalova I.G. Rekreatsionny resurs Daginskogo mestorozhdeniya termalnykh mineralnykh vod [Recreational resource of the Daginsky deposit of thermal mineral waters]. Aktualnye voprosy sovremennoy meditsiny: Materialy 70-y itogovoy nauchnoy konferentsii molodykh uchenykh $i$ studenrov [Actual problems of modern medicine: Materials of the $70^{\text {th }}$ final figure conference of young scientists and students]. Khabarovsk, DVGMU Publ., 2013. pp. 117-119.

8. Posokhov E.V., Tolstikhin N.I. Mineralnye vody: lechebnye, promyshlennye, energeticheskie [Mineral waters: medicinal, industrial, energy]. Leningrad, Nedra Publ., 1977. 240 p.

9. Rosen B.Y. Geokhimiya broma i yoda [Geochemistry of bromine and iodine]. Moscow, Nedra Publ., 1970. 144 p.

10. Suslova K.I., Chernov V.A. Daginskie termalnye istochniki kak turisticheskiy resurs Sakhalinskoy oblasti [Daginsky thermal springs as a tourist resource of the Sakhalin region]. Razvitie meditsinskoy reabilitatsii na Dalnem Vostoke [Development of medical rehabilitation in the Far East]. Khabarovsk, DVGMU Publ. house, 2016. pp. 68-70

11. Filatov D.G. Bromnye podzemnye mineralnye vody: genezis i balneologicheskie svoystva [Bromine underground mineral waters: genesis and balneological properties]. Bulletin of Voronezh State University, series: Geology, 2012, no. 2, pp. 229-235. In Rus.

12. Alcalá F.J., Custodio, E. Using the $\mathrm{Cl} / \mathrm{Br}$ ratio as a tracer to identify the origin of salinity in aquifers in Spain and Portugal. Journal of Hydrology, 2008, no. 359, pp. 189-207.

13. Barut I.F., Erdogan N., Basak E. Hydrogeochemical evaluation of western Anatolian mineral waters. Environmental Geology, 2004, vol. 45, no. 4, pp. 494-503.

14. Grasby S.E., Hutcheon I., Krouse H.R. The influence of water-rock interaction on the chemistry of thermal springs in western Canada. Applied Geochemistry, 2000, vol. 15, no. 4, pp. 439-454.

15. Horváth K., Kulisch Á., Németh A., Bender T. Evaluation of the effect of balneotherapy in patients with osteoarthritis of the hands: a randomized controlled single-blind follow-up study. Clinical Rehabilitation, 2012, vol. 26, no. 5, pp. 431-441.

16. Kralj P., Kralj P. Thermal and mineral waters in north-eastern Slovenia. Environmental Geology, 2000, vol. 39, no. 5, pp. 0488-0500.

17. Melioris L. Mineral and thermal waters of the Ipelská Pahorkatina hillyland. Environmental Geology, 2000, vol. 39, no. 5, pp. 448-462.

18. Sakharov V.A., Morozova O.A., Vypryzhkin E.N., I Ken Khi, Poliak H.S. Formation of chemical composition of injection-type mineral water deposits as exemplified by chapaevskoye field in Korsakov district of Sakhalin region. Periódico Tchê Quimi, 2019, vol. 16, no. 31 , pp. 457-471.

19. Tarcan G., Gemici U. Water geochemistry of the seferihisar geothermal aria, Izmir Turkey. Journal of Volcanology and Geothermal Research, 2003, vol. 126, no. 3-4, pp. 225-242.

20. Todorović M., Štrbački J., Ćuk M., Andrijašević J., Šišović J., Papić P. Mineral and thermal waters of Serbia: multivariate statistical approach to hydrochemical characterization. Environmental Earth Sciences, 2016, vol no, pp. 81-95.

Received: 28 January 2019

\section{Information about the authors}

Valeriy A. Sakharov, Cand. Sc., head of laboratory, Sakhalin State University.

Vladimir V. Ilin, senior lecturer, Sakhalin State University.

Olga A. Morozova, lead engineer, Sakhalin State University.

Evgeny N. Vypryazhkin, lead engineer, Sakhalin State University.

I Ken Khi, lead engineer, Sakhalin State University.

Irina V. Gogoleva, trainee, Sakhalin State University. 